\title{
ASPEK YURIDIS \\ PERJANJIAN BUSINESS FRANCHISE DI INDONESIA
}

\author{
Lily Triyana \\ Lily_tanden@yahoo.co.id \\ Dosen Fakultas Hukum Universitas Mulawarman Samarinda
}

\begin{abstract}
In Indonesia there is no regulation about franchise. Same thing is also experienced of many state, for example English and Australian. No special regulation about franchising can be consedered to be good news or is bad news. The bad news is wth no special guidance, hence goodnesss of franchisor amd also of franchisee have to reckon on written agreement in cooperation contract. Irts meaning both parties have to neglectless and meticulous to the what agreed on. Protection of other decision which arrange an cooperation of Franchising represent the source of which whereas can be made by guidance do complied agreement have the basis for real correct and fair. Association of franhcising generally realese code of ethic of franchising.good news of inexistence regulation of area of franchising is goodness of franchisor and fracnhisee earn free compromise whateverly. As hold of legal fundament of agreement of franchise in Indonesia is freedom contract such as those which arranged in section $1338 \mathrm{KUH}$ Perdata and by concidering conditions of section 1338 KUHP Perdata. Law contract in Indonesia embrace open system meaning that each and everyone is free to make all kinds of contract. In section 1338 KUH Perdata contained by the following rule all made contract lawfully will bind over them making it own. In the case conditions of 1320 section of KUH this Perdata is fulfilled by hence comand of section $1338 \mathrm{KUH}$ Perdata. The making agreement act as codellaw to all party. So franchise, and vitally hence to all party arrange agreement content detail.
\end{abstract}

Solving of dispute represent problem which in many is important to licencer, specially In the case of giving of license. Right of intellectual properties in the form of trade secret. Solving of dispute which is through jurisdiction forum, it is though enabled to be emphasized in conference closed (for the secret of trade) felt concerned abaout by licencer party will become an openly forum to receiver of license which do not good mine. To avoid the mentioned hence better each; every dispute realted to agreement of giving license finished in framework of alternative of is solving of dispute, including in it arbitrase.

Ordinary license agreement unlike giving of agreement of license of franchise. If at giving of agreement of license usually only covering giving of permission cover all sort of kinds of intellectual property that appliances bought or rented from him. Besides so-called above, agreement of franchise are; giving of license abaout name of trading, model brand, desain, ets. Rules that can be grouped in the field of contractual law and in the field of law about intellectual property.

Key words: differentiate franchise, of law facet, law of frachise entangle contractual law areas, specially abaout giving of license, special regulation about franchising, and Ordinary license agreement 


\section{PENDAHULUAN}

Pengaruh globalisasi dalam berbagai bidang telah menyebabkan berubahnya tatanan budaya masyarakat. Tidak dapat dipungkiri bahwa apa yang terjadi dalam belahan bumi utara akan segera terjadi pada belahan bumi selatan. Kemajuan teknologi informasi dan teknologi transportasi sebagai akibat dari kemajuan ilmu pengetahuan dan teknologi, menyebabkan jarak antar tempat semakin dekat. Oleh karena itu apa yang dulu tidak dikenai pada suatu tempat tertentu, sekarang ini sudah dapat diperoleh dengan cepat dan mudah.

Saat ini pengembangan usaha melalui sistem franchise mulai banyak diterapkan oleh perusahaan-perusahaan di Indonesia. Dalam rangka membantu pengembangan usaha melalui sistem franchise tersebut, Direktorat Jendral Perdagangan Republik Indonesia ,menugaskan Institut Pendidikan dan Pembinaan Manajemen (IPPM) untuk mengadakan suatu penelitian mengenai kebijakan-kebijakan yang perlu diambil untuk membina, mengembangkan, dan melindungi usaha franchise di Indonesia. Sebagai suatu cara pemasaran dan distribusi, franchise merupakan suatu alternatif di samping saluran konvensional yang dimiliki perusahaan sendiri. Cara ini memungkinkan untuk mengembangkan saluran eceran yang berhasil tanpa harus membutuhkan investasi besar-besaran dari perusahaan induknya. Akibat kebutuhan investasi yang terus meningkat untuk mengembangkan usaha eceran, franchise tampaknya memberikan cara yang dapat digunakan bagi para pengecer spesialis untuk mengembangkan diri di masa yang akan datang.

Dalam pembukaan Undang-Undang Dasar 1945 alinea ke IV disebutkan .... Untuk membentuk suatu pemerintahan Negara Indonesia yang melindungi segenap bangsa Indonesia dan seluruh tumpah darah Indonesia, dan untuk memajukan kesejahteraan umum, mencerdaskan kehidupan bangsa .... Dalam alinea tersebut merupakan tujuan nasional seiring dengan usaha pemerintah untuk mencapai tujuan nasional tersebut, maka pemerintah harus membangun aspek berbagai kehidupan , dimana penerapannya harus selaras, serasi dan seimbang. Dengan demikian apabila terjadi hal-hal ynag tidak diinginkan akan segera di atasi . Aspekaspek tersebut, antara lain aspek ideologi , hukum, politik, sosial, ekonomi, budaya,pertahanan dan keamanan.

Peran serta pemerintah dalam kehidupan ekonomi sangat besar, namun untuk mencapai tujuan ekonomi maka perlu dibangun aspek hukum . Hukum yang kuat, mengakibatkan perekonomian akan kuat.

Upaya pemerintah dalam memajukan aspek hukum untuk kemajuan ekonomi antara lain dengan diundangkan. Undang - undang mengenai Penanaman Modal Dalam Negeri dan Undang - undang mengenai Penanaman Modal Asing . Dengan adanya undang-undang tersebut, maka pemerintah memperluas arus perdagangan, arus teknologi ,ilmu pengetahuan untuk menunjang kemajuan serta peningkatan di berbagai aspek kehidupan. Franchise merupakan salah satu bentuk kerja sama dengan yang populer saat ini. Merupakan salah satu konsekuensi adanya Undang-undang tersebut.

Perjanjian franchise merupakan dokumen yang didalamnya, seluruh transaksi dijabarkan secara bersama, yaitu mengatur hak dan kewajiban masingmasing pihak (franchisor dan franchisee). Perjanjian franchise harus secara tepat menggambarakan janji-janji yang harus dibuat dan harus adil, serta pada saat yang bersamaan menjamin bahwa ada kontrol 
yang cukup untuk melindungi integritas sistem .

Perjanjian Franchise haruslah :

1. Dibuat dengan benar, sesuai dengan persyaratan hukum, dengan beragam hak milik yang dimiliki franchisor;

2. Memberikan detail-detail operasional dan kontrol;

3. Memberikan franchise jaminan dalam beroperasi dan pada kemampuannya untuk mengembangkan dan menjual asetnya. (Mendelson 1997,55)

Franchise telah tumbuh dengan pesatnya keseluruh dunia dalam tiga dekade terakhir. Tingkat pertumbuhan yang terjadi tigasampai empat tahun yang lalu dan tingkat pertumbuhan yang diproyeksikan, menunjukan bahwa perkembangan tersebut terus meningkat .

Peraturan franchise di Indonesia daitur dalam PP No. 16 tahun 1997 tentang Waralaba dan Keputusan Menteri Perindustirian dan Perdagangan No. 259 /MPP/Kep/7/1997 tentang Tata Cara Pelaksanaan Pendaftaran Usaha Waralaba . Dalam tulisan ini penulis ingin membahas franchise dari aspek yuridisnya.

\section{HASIL DAN PEMBAHASAN}

\section{Pengaturan Hukum Perjanjian Bisnis Franchise Dalam Kerangka Hukum Nasional Indonesia}

Hingga saat ini kerangka hukum format yang terpenting yakni hukum perjanjian atau hukum kontrak belum terbentuk sehingga setiap aktifitas bisnis yang menyangkut hal didasarkan hanya kepada KUH Perdata serta KUH Dagang. KUH Perdata sendiri merupakan produk hukum peninggalan kolonial Belanda yang tentu saja isinya memiliki nilai dan pandangan yang berbeda situasi masyarakat
Indonesia dewasa ini. Selain itu berkembangnya perekonomian global telah mengakibatkan pula KUH Perdata semakin tidak mengimbangi aktifitas bisnis yang terjadi dalam praktek.

Hal ini tentu mengakibatkan terjadinya ketidakseimbangan antara perkembangan aktifitas bisnis dengan perkembangan pengaturan hukum sehingga timbul kekosongan hukum. Kondisi ini sangat tidak menguntungkan bagi perkembangan dunia bisnis di Indonesia.

Kenyataan di atas tentu saja harus diantisipasi secara positif dengan membentuk pengaturan yang dibutuhkan. Hingga saat ini seringkali pengaturan yang terbentuk lebih bersifat praktis yakni dalam bentuk kebijakan pemerintahan yang sifatnya terbatas pada pengaturan dalam rangka mengantisipasi situasi tertentu juga.

Perkembangan bisnis yang pesat apabila dikaitkan dengan perdagagan dan investasi maka membutuhkan ketentuan berupa produk hukum yang membuka kesempatan yang seluas-luasnya di dalam membina hubungan bisnis dengan memperhatikan kepentingan masyarakat banyak di Indonesia serta tanpa mengabaikan kedudukan Indonesia dalam dunia Internasional. Sehubungan dengan permasalahan franchise dalam pengaturannya di dalam kerangka hukum nasional Indonesia, maka sudah saatnya pengaturan mengenai pemasalahan ini diatur secara tersendiri dalam produk hukum tertentu. Uraian di atas mengenai terdapatnya dua segi yang harus diperhatikan dalam pembentukan suatu produk hukum memperhatikan kepentingan masyarakat Indonesia, sedangkan di lain pihak harus pula memperhatikan kedudukan Indonesia sebagai bagian dari dunia internasional harus menjadi bahan pertimbangan utama dalam pembuatan produk hukum yang baik. 
Pada tanggal 18 Juni 1997 Presiden telah mengatur secara positif hukum yang berlaku bagi bisnis Franchise di Indonesia dengan menetapkan Peraturan Pemerintah No. 16 tahun 1997 tentang Waralaba, terdiri dari 11 (sebelas) pasal (selanjutnya disebut PP 16/97) . Penulis berpendapat bahwa isi PP 16/97 masih bersifat terlalu umum dan kurang menyeluruh sehingga hal-hal yang tercantum didalamnya diatur dengan sangat singkat dan kurang memadai untuk dapat digunakan sebagai peraturan dasar atau sumber hukum utama untuk menata kegiatan Franchise di Indonesia. ${ }^{15}$

Seperti telah hdiuraikan di atas bahwa bagi Indonesia penyusunan produk hukum yang baik adalah produk hukum yang sejalan dengan memperhatiakn kedudukannya di dunia Internasioanl. Akan tetapi, isi dari PP No.16 / 97 terkesan kurang memperhatikan kedudukan Indonesia dalam dunia Internasional. Hal ini tentu dapat menyulitkan Indonesia di dalam perdagangan Indonesia terutama menyongsong era pasar bebas.

Pengaturan PP 16 / 97 masih memerlukan cukup banyak peraturan yang bersifat lebih teknis yang mungkin berupa Surat Keputusan Menteri . Hingga tulisan ini di buat peraturan yang bersifat lebih teknis tersebut belum terbit, diharapkan isi dari pengaturan teknis ini dapat membantu memperjelas maksud serta arah PP 16/97.

\section{Format Pengaturan mengenai Bisnis Franchise di Indonesia}

Apabila dilihat mengenai praktek bisnis Franchise bahwa belum terdapat keseragaman pengaturan di dalam perjanjian Franchise antara para pihak. Isi dari perjanjian yang dilakukan oleh para pihak tergantung pada kehendak para pihak. Seringkali pihak franchisor terutama franchisor asing memiliki kekuatan untuk memaksakan kepentingannya di dalam perjanjian franchise, sehingga pihak franchisee seringkali berada dalam posisi tawar yang kurang menguntungkan. Hal ini seharusnya tidak terjadi apabila terdapat pengaturan yang memuat mengenai syaratsyarat minimal yang harus ada dalam sebuah perjanjian franchise. Hubungan antara franchisor dan franchisee yang timbul dalam praktek di Indonesia terutama hanya didasarkan pada perjanjian Franchise yang disepakati. Pengaturan dari perjanjian pada umunya sampai saat ini bernaung di bawah pengaturan buku III KUH Perdata, sehingga ketentuan umum dari buku III KUH Perdata ini berlaku pula bagi perjajian Franchise yang disepakati.

Buku III KUH Perdata menganut asas kebebasan berkontrak yakni suatu asas yang memberikan kebebasan bagi para pihak untuk mengatur hubungan yang timbul diantara mereka asalkan hal yang disepakati tidak bertentangan dengan kepentingan umum, ketertiban dan kesusilaan, selain itu harus pula diperhatikan mengenai syarat-syarat sahnya persetujuan. Kedua hal terpenting ini lah selain hal-hal umum lainnya dalam buku III KUH Perdata yang selama ini merupakan hukum positif yang mengatur perjanjian di Indonesia.

Sehingga. Pengaturan Buku III KUH Perdata yang mengatur mengenai kebebasan berkontrak serta syarat sahnya persetujuan san hal-hal umum lainnya yang mengatur mengenai perjanjian secara otomatis harus dipenuhi dalam menyusun perjanjian Franchise.

Hal terpenting yang selayaknya dibangun di Indonesia adalah kerangka mengenai hukum perjanjian karena dalam dunia bisnis modern semakin banyak ditemukan perjanjian-perjanjian dan praktek bisnis-bisnis yang mengandung unsur kurang adil terhadap pihak yang lebih lemah. Unsur ini seringkali terdapat dalam klausula-klausula perjanjian yang 
menyebabkan keuntungan yang diperoleh tidak sebanding antara satu pihak dengan pihak lain.

Sedangkan berhubungan dengan masalah Franchise, untuk mengimbangi perkembanngannya sudah saatnya dipikirkan suatu produk hukum yang secara khusus mengatur mengenai keberadaaan Franchise di Indonesia. Seperti yang telah diuraikan dalam sub bab sebelumnya bahwa telah disahkannya PP 16/97 telah membawa suatu perkembangan baru di dalam pengaturan uhukum mengenai Franchise di Indnoesia. ${ }^{16}$

PP 16/97 terdiri dari 11 (sebelas) pasal, secara umum akan diuraikan isi dari PP yang menurut pwnulis patut dicermati.

Pasal 2(2) PP 16/97 mengatur bahwa :

"Perjanjian Waralaba dibuat dalam bahasa Indonesia dan terhadapnya berlaku hukum Indonesia".

Kewajiban untuk menyusun perjanjian dalam bahasa Indonesia menurut penulis hal ini agak dipaksakan karena kenyataannya di Indonesia hingga saat ini perjanjian Franchise yang terjalin di pihak franchisor berasal dari luar Indonesia maka sudah dapat dipastikan perjanjian yang disepakati ditulis dengan bahasa asing.

Selain itu penulis berpendapat masalah redaksi perjanjian yang berbahasa asing seharusnya tidak perlu menjadi masalah yang serius karena perjanjian yang dapat diterjemahkan dalam bahasa Indonesia.

Di samping itu, pemberlakuan hukum Indonesia bagi setiap perjanjian Franchise menurut pendapat penulis akan menimbulkan masalah karena perangkat hukum di Indonesia belum cukup siap untuk menerima perubahan ini baik secara umum yakni mengai hukum perjanjian masih mengandalkan pada pengaturan dari Buku III KUH Perdata yang dbiakui oleh para pakar hukum di Indonesia bahwa pengaturan tersebut sudah tidak memadai di dalam mengantisipasi perkembangan bisnis maupun Franchise yaitu PP 16/97 . Hal ini dapat menimbulkan kekosongan pengaturan hukum sehingga terdapat kemungkinan dari salah sati pihak mendapat keuntungan dari hal ini.

Secara khusus untuk Franchise Internasional Indonesia mereka lebih condong untuk memilih hukum asing untuk mengatur perjanjian Franchise. Perlu disadari bahwa tidak tertutup kemungkinan bahwa pemilihan hukum asing justru dapat menguntungkan pihak franchisee karena pengaturan yang terdapat di dunia Internasional sudah lebih memperhatikan kedudukan franchisee agar tidak dirugikan. Sedangakn pengaturan dalam PP 16/97 terkesan tidak terdapat unsur perlindungan bagi Franchisee.

Selain itu pengaturan dari PP 16/97 mengenai keharusan untuk memilih hukum Indonesia bagi setiap perjanjian Franchise yang ada menutup kemungkinan para pihak untuk melakukan choise of law ( pilihan hukum), apabila gejala ini dikaitkan dengan asas kebebasan berkontrak sebagaimana yang dianut dalam KUH Perdata hal ini akan menimbulkan ketidakseinkronan pengaturan hukum yang terdapat di Indonesia khususnya yang mengatur masalah Franchise.

Pasal 3 ayat (1) PP 16/97 secara garis besar mensyaratkan suatu dokumen yang harus disiapkan oleh franchisor guna memberikan informasi yang sejelasjelasnya secara akurat kepada pihak franchisee.

Pasal 3 ayat (1), dan penjelasan Pasal 3 ayat (1) PP 16/97berisikan hal-hal sebagai berikut :

1. Sebelum membuat perjanjian, pemberi waralaba wajib menyampaikan keterangan kepada penerima waralaba secara tertulis dan benar sekurang-kurangnya mengenai:

a. Pemberi Waralaba berikut keterangan mengenai kegiatan 
usahanya;

Penjelasannya: Keterangan mengenai pemberi waralaba menyangkut identitasnya antara lain nama dan atau alamat tempat usaha, nama dan alamat pemberi waralaba, pengalaman mengenai keberhasilan dan kegagalan selama menjalankan waralaba, keterangan mengenai waralaba yang pernah dan masih melakukan perikatan dan kondisi keuangan.

b. Hak atas kekayaan intelektual atau penemuan atau ciri khas usaha yang menjadi obyek waralaba;

c. Persyaratan-persyaratan yang harus dipenuhi penerima waralaba;

Penjelasannya: Persyaratan yang harus dipenuhi penerima waralaba anatara lain mengenai cara pembayaran, ganti rugi, wilayah pemasaran, pengawasan mutu.

d. Bantuan atau fasilitas yang ditawarkan pemberi waralaba kepada penerima waralaba;

Penejelasannya: Keterangan mengenai prospek kegiatan waralaba, meliputi juga dasar yang dipergunakan dalam pemberian keterangan tentang prospek yang dimaksud.

e. Hak dan Kewajiban Pemberi dan Penerima Waralaba

Penjelasannya: Bantuan atau Fasilitas yang diberikan antara lain berupa pelatihan, bantuan keuangan, bantuan pemasaran, bantuan pembukuan dan pedoman kerja.

f. Pengakhiran, Pembatalan, Perpanjangan perjanjian waralaba serta lain-lain yang perlu diketahui penerima waralaba dalam rangka pelaksanaan perjanjian waralaba.

Pengaturan ini menurut pendapat penulis bersifat positif karena akan melindungi pihak franchisee, karena franchisee yang memutuskan untuk memasuki sistem franchise tertentu telah mendapat gambaran mengenai bisnis yang akan dimasuki.

Sebagai pembanding di Amerika Serikat terdapat kewajiban penerbitan dokumen pengungkapan semacam prospektuas yang disebut UFOC oleh para franchisor apabila hendak menawarkan sistem franchisenya.

Uaraian di isi UFOC di Amerika Serikat memberikan gambaran bahwa pasal Pasal 3 ayat (1) PP 16/97masih membutuhkan penyempurnaan lebih lanjut, agar dokumen awal yang dibuat benarbenar dapat membantu franchisee untuk mendapatkan gambaran yang menyeluruh mengenai bisnis franchise yang akan dimasuki.

Pasal 6 ayat (1) berikut penjelasan pasal 6 ayat(1) PP 16/97 menyatakan bahwa :

"Usaha waralaba dapat diselenggarakan untuk dan di seluruh wilayah Indonesia, dan pelaksanaannya dilakukan secara bertahan dengan memperhatikan perkembangan sosial dan ekonomi dan dalam rangka pengembangan usaha kecil dan menengah".

"Penyelenggaraan waralaba pada dasarnya dilakukan secara bertahap terutama di Ibukota Propinsi. Pengembangan waralaba di luar ibukota, seperti Ibukota kabupaten / kotamadya Daerah Tingkat II dan tempat-tempat tertentu lainnya yang memerlukan kehadiran jasa waralaba dilakukan secara bertahap dan memperhatikan keseimbangan antara kebutuhan usaha dan tingkat pertumbuhan sosial dan ekonomi terutama dalam rangka pengembangan usaha kecil dan menengah di wilayah yang bersangkutan".

Penulis berpendapat pengaturan pada bagian ini tidak memberikan pengertian yang jelas mengenai pengaturan wilayah yang disyaratkan pemerintah. Pembatasan 
pengembangan usaha Franchise menurut pendapat penulis akan justru dapat merrugikan pengembangan sistem Franchise di Indonesia, karena usaha Franchise yang selama ini beroperasi di daerah kabupaten / kotamadya Daerah Tingkat II menjadi tidak jelas kedudukannya yakni setelah pengaturan ii efektif berlaku apakah mereka masih diperbolehkan beroperasi. Selain itu apakah pembatasan semacam ini selaras dengan pengaturan Internasional yang justru mengisyaratkan suatu perdagangan yang bebas.

Permasalahan mengenai pengaturan wilayah ini menurut penulis ada baiknya diatur dengan baik dan terperinci maksud dari pengaturan tersebut secara jelas, akan tetapi sejalan dengan persiapan bangsa Indonesia dalam menghadapi era perdagangan bebas alangkah baiknya pengaturan dari PP 16/97 menyinggung pula mengenai persoalan kemitraan usaha. Pengaturan kemitraan usaha dengan menggunakan pola Franchise penting dibahas agar Usaha Kecil dan Menengah mendapatkan bantuan untkuk meningkatkan keberadaannya sehingga pada gilirannya dapat diperkuat basis perekonomian bangsa Indonesia.

$$
\text { Pasal } 7 \text { ayat (1) PP 16/97 }
$$
mensyaratkan bahwa :

"Perjanjan waralaba beserta keterangan tertulis sebagaiman dimaksud pada pasal 3 ayat (1) di daftarkan di Departemen Perindustrian dan Perdangan oleh penerima waralaba pa;ing lambat 30 (tiga puluh) hari terhitung sejak tanggal berlakunya perjanjian".

Penulis berpendapat apakah dengan di daftarkan perjanjian yang telah terbentuk kepala Departemen akan membawa dampak positif bagi para pihak. Misalnya : Apabila terdapat hal yang mengatur mengenai hak dan kewajiban para pihak secara tidak seimbang maka Departemen dapat melakukan uoaya nyata seperti mensyaratkan perjanjian tersebut untuk diperbaiki kembali hingga kedudukan para pihak seimbang. Kalaupun upaya itu memang dilakukan oleh Departemen, maka hal ini akan mensyaratkan suatu bagian yang khusus untuk menangani masalah ini.

Secara Keseluruhan PP 16/97 menurut pendapat penulis masih belum terlalu dapat memberikan sumbangan yang nyata bagi penataan hukum dan perkembangan bsinis Franchise di Indonesia, bahkan pengaturan ini terkesan membendung perkembangan Franchise terkhususnya Franchise Internasional di indonesia. Memang di satu pihak pemerintah berkewajiban untuk membina pengusaha menengah dan pengusaha kecil namun bukan berarti menutup perkembangan dari pengusaha besar yang telah beroprasi dengan menggunakan sistem Franchise.

Sehubungan dengan perlindungan pengusaha kecil yang diupayakan melalui UU Usaha Kecil, dimana UU tersebut menyatakan bahwa pemerintah bermaksud memberdayakan pengusaha kecil agar dapat bersaing dalam mengahdapi era perdagangan bebas.

Pemberdayaan usaha kecil ini dilakuakn melalui program kemitraan yang disyaratkan bahwa pengaturan tentang kemitraan akan diatur lebih lanjut dengan Peraturan Pemerintah. Kemitraan dapat berbentuk modal ventura, kontrak farming, waralaba, dan lain-lain.

PP 16/97 ini menurut pendapat penulis kurang memperhatikan unsur pembinaan dan pengembangan terhadap usaha kecil dan usaha menengah bahkan nyaris tidak memberikan perlindungan.

Jika dikaitkan dengan keinginan untuk meningkatkan pemberdayaan Usaha Kecil melalui Program kemitraan yang dimaksud oleh UU No. 9 tahun 1995 tentang Kemitraan Usaha Kecil maka penukis berpendapat bahwa sepatutnya Peraturan 
Pemerintah yang diatur terlebih dahulu yaitu mengenai Kemitraan. Setelah itu baru dibuat Peraturan Pemerintah lainnya yang mengatur berbagaiu jenis dari kemitraan yang ada.

Kalaupun memang pengaturan mengenai jenis Franchise tealha mendesak pengaturannya dapat saja dimungkinkan pengaturannya diatur terlebih dahulu akan tetapi jangan sampai terlepas dari mis semula yaitu memberdayakan usaha kecil dalaam upaya menyongsong era perdagangan bebas.

Seharusnya mengenai pengaturan utama PP 16/97 memuat aturan-aturan yang mendorong bagi perkembangan usaha kecil di Indonesia melalui pola Franchise yang semakinn banyak digunakan secara Internasional. Akan tetapi, di dalam PP 16/97 sama sekali tidak mencantumkan misi semula yang ingin dicapai, hal ini dapat dilihat dari tujuan pengaturan ini disebutkan sebagai upaya untuk menciptakan tertib usaha dengan cara waralaba serta perlindungan terhadap konsumen, dipandang perlu menetapkan ketentuan tentang Waralaba dengan Peratuaran Pemerintah.

Bahkan PP 16.97 ini mendasarkan pengaturannya hanya mengingat pengaturan pasal 4 (1) Undang-undang Dasar 1945, Kitab Undang-undang Hukum Perdata, Undang-undang pengaturan perusahaan 1934 (Bedrifs Reglementerings Ordonontoe 1934, Staatblads 1938 Nomor 86) dan sama sekali tidak mendasarkan pengaturannya pada UU No 9 Tahun 1995 tentang Usaha Kecil.

PP 16/97 ini menuntut pengaturan pelaksana yang lebih praktis segera terwujudkan. Hal ini membutuhkan kerja keras dari Departemen yang ditunjuk agar dalam waktu yang singkat sudah dapat menyiapkan pengaturan yang lebih bersifat tekinis.
Departemen Koperasi danPembinaan Pengusaha Pengusaha Kecil telah berusaha memberikan arahan yang bersifat praktis bagi para franchisor dan franchisee di dalam membangun siste franchise. Hal ini merupakan contoh yang dapat dipertimbangkan agar dlaam pengaturan yang bersifat teknis yang akan disusun lebih lanjut isinya mengatur hal-hal yang teknis secara menyeluruh.

Selain hal tersebut diatas penulis berpendapat bahwa perlu menghidupkan suatu iklim berorganisasi yang sehat, hal ini daapt dilakukan melalui Asosiasi Franchise Indonesia (selanjutnya disingkat AFI) dan Asosiasi Waralaba Indonesia (selanjutnya disingkat ARWI) Asosiasi yang ada ini kiranya dapat berfungsi untuk menaungi anggotanya sehingga mereka semua mendapat manfaat maksimal dari keanggotaannya. Sebagai contoh British Franchise Asociation mempunyai kegiatan yang sangat positif di dalam rangka membina para anggotanya, yakni dengan mengadakan pertemuan berkala, seminar, dan kegiatan lainnya dalam usaha membangun keberadaan para anggota.

Kesemua hal yang dikemukakan di atas secara singkat memberikan gambaran bahwa masih banyak pembenahan yang harus dilakukan oleh segenap pihak yang terkait dengan masalah Franchise baik itu pemerintah, para franchisor, maupun para franchisee.

\section{Usulan Pengaturan Hukum Mengenai Bisnis Franchise di Indonesia}

Pada tahun 1995 diterbitkan pula suatu Pedoman Pelaksanaan Keterkaitan Kemitraan di Bidang Industri Kecil yang isinya memuat mengenai pedoman kemitraan yang dapat melaksanakan dengan berbagai cara salah satunya dengan pola Franchise. Secara singkat dapat diuraikan 
bahwa pedoman tersebut memuat mengenai pengertian franchise, tipe franchise, syarat an kewajiban sebgai franchisor dan franchise, serta bidang usaha yang potensial dikembangkan dengan sistem franchise. Hal ini merupakan langkah awal yang cukup positif dalam rangka pembinaan usaha kecil dan usaha menengah.

Sebagai tindak lanjut dari usaha diatas , dalam rangka melakukan pembinaan terhadap pemahaman pengusaha kecil di Indonesia khususnya dalam hal bisnis dengan menggunakan pola Franchise telah menerbitkan dua Format Bisnis Franchise dalam bidang makanan dan bidang distribusi / keagenan produk pakaian di Indonesia. Hal ini dilakasakan dalam rangka untuk memacu pertumbuhan dan perkembangan usaha kecil dan usaha menengah untuk menerapkan sistem Franchise.

Kedua Format bisnis yang disusun tersebut secara garis besar akan diuraikan pembahasan berikut ini. Format bisnis Franchise pada dasarnya adalah suatu sistem untuk mempersiapkan suatu bisnis apakah memenuhi syarat untuk di franchisekan, serta prosedur-prosedur apakah yang harus dan peralatan-peralatan apakah yang dibutuhkan (termasuk aspek landasan hukum).

Persyaratan dan prosedur yang merupakan suatu kesatuan yang utuh yang diperlukan untuk menguji apakah suatu perusahaan dapat menjadi franchisor, adalah :

\section{Pengalaman bisnis (business experience)}

Perusahaan yang memenuhi syarat sebagai franchisor harus memiliki pengalaman bisnis minimal 3 (tiga) tahun secara terus menerus. Hal ini menurut penulis penting karena pengalaman bisnis yang cukup akan membantu franchisor memahami secara baik mengenai seluk- beluk bisnisnya. Selain itu, hal ini diperlukan untuk melindungi para franchisee dari ptaktek penjualan franchise oleh franchisornya secara tidak bertanggung jawab.

\section{Kemampuan (profitability)}

Labaan

Persyaratan selanjutnya adalah perusahaan yang akan di franchisekan harus terbukti memiliki daya untuk mendatangkan laba cukup tinggi. Hal ini penting karena franchise dapat terjebak dalam perusahaan yang ternyata tidak bisa menghasilkan laba yang sesuai dengan biaya yang dikeluarkan untuk pembelian sitem franchise.

\section{Kemampuan Pasar dan Merek Dagang (marketability and trade mark)}

Produk atau jasa dari perusahaan calon franchisor harus terbukti melalui suatu pengkajian pasar, dapat dipasarkan secara luas dan merek dagang dari perusahaan tersebut harsu dikenal. Studi mengenai kemampuan pasar dan dikenalnya merek dagang dapat dilakukan melalui riset pasar. Hal ini merupakan hal yang penting yang harus diketahui para franchise sebelum memutuskan untuk masuk dalam sistem franchise tertentu.

\section{Kemampuan Ajar (teachability)}

Sistem bisnis yang terlalu rumit dan memakan waktu yang lama untuk diajarkan kepada pihak lain maka akan sulit memenuhi syarat untuk dikembangkan secara franchising. Persyaratan ini penting diketahui karena perusahaan yang ingin mengembangkan dirinya sebagai franchisor harus mengetahui sampai sejauh mana kerumitan dari sistem bisnisnya.

\section{Kemampuan (transferability)} alihan 
Hal ini berkaitan dengan kemampuan dari produk atau jasa apakah sesuai dengan selera, kebiasaan serta pola konsumen di suatu daerah tertentu sehingga dapat diterima oleh masyarakat setempat. Penilaian hal ini penting karena apabila suatu produk atau jasa sebaik apapun apabila tidak sesuai dengan selera pembeli maka tidak akan ada peminat.

\section{Keorisinilan (originality)}

Keorisinilan suatu produk barang atau layanan jasa sangat penting, karena pelayanan dan penyajian yang unik dapat memberikan nilai tambah terhadap keberhasilan pemasaran barang atau jasa yang bersangkutan melalui pola Franchising.

\section{Keterjangkauan (affordibility)}

Persyaratan ini merupakan perhitungan finansial apakah franchisee dapat memperoleh daya laba, berapa lam akan mencapai titik impas. Hal ini harus sangat diperhatikan oleh franhcisee karena franchisee harus memperhitungkan sampai berapa lama ia mampu mengembalikan investasinya.

\section{Anak Perusahaan (company owned unit)}

Persyaratan lainnya yang juga penting sebagai salah satu kriteria untuk menjadi franchisor adalah perusahaan tersebut sebaiknya memiliki 1 (satu) anak cabang perusahaan sendiri. Hal ini selain membantu franchisor untuk lebih memahami seluk bisnisnya juga dapat membantu franhcisee dalam menghadapi persoalan operasional. (Dirjend.pembinaan pengusaha kecil departemen koperasi dan pembinaan pengusaha kecil 1995)

Kedelapan hal tersebut diatas menurut penulis bukan saja penting untuk franchisor di dalam mempersiapkan sitem franchise, tapi juga penting bagi franchisee sebagai dasar untuk menilai apakah franchisor dan sitem franchise yang ditawarkan memang memberikan keuntungan yang baik.

Penulis berpendapat bahwa Surat Keputusan Menteri yang akan di buat untuk pengaturan lebih teknis bisnis Franchise di Indonesia sebaiknya juga mengatur mengenai hal diatas. Hal ini penting diatur karena selain persyaratan yang diwajibkan dalam Pasal 3 ayat (1) PP 16/97, maka kedelapan hal yang telah dikemukanan di atas dapat membantu franchisee apabila akan memasuki bisnis tertentu.

Format Bisnis Franchise tersebut memaparkan pula mengenai persyaratan ideal yang harus dipenuhi dalam suatu perjanjjian bisnis Franchise sebagai berikut: bagian pendahuluan yang berisikan mengenai objek yang difranchisekan, kemudian diatur mengenai persyaratan franchisee, jangka waktu perjanjian, kekamndirian dalam arti pihak keduanya bersifat independen dalam arti berdiri sendiri, biaya franchise, bantuan yang diberikan franchisor, nama usaha usaha franchisee, lokasi usaha franhchisee, tahap pra operasi, tahap operasi, waktu kerja, penggantian dan pembiayaan biaya, pajakpajak, modifikasi sistem, tanda dan merek, asuransi, pemeriksaan usaha dan tempat usaha, pindah lokasi, laporan operasional dan biaya administrasi, perpanjangan franhcise, biaya perpanjangan franchise, sanksi apabila beroperasi tanpa memperpanjang perjanjian, rahasia sistem, pengehentian perjanjian, prosedur setelah penghentian, perubahan perjanjian, integritas perjanjian, milik eksklusif, serta domisili hukum. Keseluruhan unsur yang tercantum sebagai pokok-pokok dalam perjanjian franchise diatas menurut penulis telah memenuhi syarat minimal dari segi hukum dan memenuhi kriteria sebagai perjanjian yang cukup baik dan 
memberikan perlindungan yang cukup seimbang bagi kedua belah pihak.

Usaha positif yang dilakukan oleh Departemen Koperasi dan Pembinaan Pengusaha Kecil ini menurut penulis secara minimal telah memenuhi syarat untuk dapat dipakai oleh para pihak yanh berkepentingan dengan bisnis Franchise.

Format bisnis yang dijadikan percontohan telah disusun cukup baik dan menyentuh segenap aspek, sebagai bahan masukan dalam menyusun pengaturan lebih lanjut yang berupa Surat Keputusan Menteri agar Format bisnis yang disusun ini dapat mengembangkan usaha pengembangan franchise di Indonesia.

Penulis berpendapat bahwa pengaturan mengenai isi minimum dari perjanjian Franchise yang akan ditandatangani sebaiknya diatur pula dalam PP 16/97 atau dalam peraturan pemerintah baru yang dibuat untuk menyempurnakan PP 16/97 dan bukan dengan produk hukum yang berupa surat keputusan menteri. Pengaturannya lebih baik berupa pengaturan pemerintah karena untuk pengaturan ini lebih menjamin unsur kepastian hukum sehingga dapat menjadi daya tarik bagi calon-calon franhcisor asing di indonesia.

\section{KESIMPULAN DAN SARAN}

\section{A. Kesimpulan}

Karena belum adanya aturan khusus dalam peraturan perundang-undangan di Indonesia mengenai kontrak perjanjian franchise, maka azaz kebebasan berkontrak di jadikan sebagai dasar dalam membuat perjanjian bisnis franchise.

Dalam perjanjian bisnis franchise, bagi franchisor dan franchisee azas kebebasan berkontrak terletak pada saat mereka mendatangani draft perjanjian kontrak dan dianggap telah tahu dan membaca isi pasal-pasal dalam perjanjian bisnis franchise tersebut.
Dalam perjanjian bisnis franchise harus dibuat secara tertulis.Karena perjanjian bisnis franchise dibuat secara tertulis maka harus di daftarkan ke Direktorat Jenderal HAKI untuk memberikan perlindungan hukum baik bagi franchisor maupun franchisee.

Penyelesaian dalam pelanggaran kontrak bisnis franchise dapat melalui proses litigasi maupun non litgasi.

\section{B. Saran}

Bagi pemerintah, perlu adanya peraturan khusus yang mengatur tentang perjanjian bisnis franchise. Sehingga terjamin perlindungan hukum bagi para fanchisor dan franchisee.

Dalam proses persetujuan dan penandatangagan kontrak perjanjian bisnis franchise, sebaiknya ada beberapa saksi yang menyertai.

Hendaknya dalam perjanjian bisnis franchise di buat di hadapan notaris.

Dalam kontrak bisnis perjanjian franchise, cara penyelesaian terhadap pelanggaran kontrak bisnis perjanjian harus jelas proses litigasi atau non litigasi yang akan ditempuh.

Dalam penyelesaian terhadap pelanggaran kontrak bisnis franchise hendaknya selalu mengutamakan alternatif penyelesaian sengketa di luar pengadilan.

\section{DAFTAR PUSTAKA}

Amir Karamoy. 1996.Sukses Lewat Waralaba. P.T.Jurnalindo Aksara Grafika.Jakarta

B.Simatupang, Richard. 1992. Aspek-aspek Hukum dalam Bisnis. P.T. Rineka Cipta. Jakarta

Fuady, Munir.2001 Hukum Kontrak (dari sudut Pandang Hukum Bisnis). P.T. Citra Aditya Bakti. Bandung 
Franchise dalam menunjang Pembanguna Ekonomi di Jakarta, 14-16 Desember 1993.BPHN.Jakarta

Hardjowidigdo, Rooseno.1993. Perspektif PengaturanPerjanjianFranchise.Maka lah Pertemuan Ilmiah Tentang Usaha

Hukum Bisnis Lisensi . P..T.Raja Grafindo Persada. Jakarta

Harsono Abi Sunarto.1989.Hak Milik Intelektual Khusunya Paten dan Merek. Akademika Presindo . Bandung

Insan, Budi Maulana. 2000. Pelangi HAKI dan Anti Monopoli. Pusat Studi Hukum FH UII Yogyakarta

Keputusan Menteri Perindustrian dan Perdagangan Republik Indonesia No 259/MPP/Kep/7/1997 tentang ketentuan dan Tata cara pelaksanaan Pendaftaran Usaha Waralaba

Martin Mendelshon. 1997. Franchising Petunjuk Praktus Bagi Franchisor dan Franchisee.P..T. Pusatak Binaman Presindo. Jakarta

Murti Sumarni, Johan Suprihanto. 1999. Pengantar Bisnis Dasar-dasar Ekonomi Perusahaan. Liberty. Jakarta

Peraturan Pemerintah No 16 Tahun 1997 tentang Waralaba. LN No 49 Tahun 1998.TLN No.3689

Ruslan Shaleh.1987. Seluk Beluk Praktis Lisensi. Sinar Grafika. Jakrta

Saidin. 1997. Aspek Hukum Hak Kekayaan Intelektual. Penerbit P.T. Raja Grafindo Persada . Jakarta

Sembiring Sentosa. 2002. Prosedur Dan Tata Cara Memperoleh Hak Kekayaan Intelektual. Cetakan Pertama. Penerbit Irama Widya. Bandung

Subekti. 1975. Pokok-pokok dari Hukum Perdata. P.T. Intermasa. Jakarta

Sumardi, Juanjir. 1995 Aspek-aspek Hukum Franchise dan Perusahaan
Trans Nasional.P.T. Citra Aditya Bhakti.Bandung

Sunandar Turyang.1996. Persaingan Yang tidak wajar dalam dunia bisnis Indonesia.

Jurnal Hukum Indonesia. Jurnal Hukum Ekonomi. Edisi IV.Mei 1996

Undang-Undang Dasar 1945. Bina Pustaka Tama. Surabaya

V, Winarto . 1991. Ceramah : Profit Franchising di Indonesia. Departemen Perdagangan. Jakarta

V, Winarto. 1995. Pengembangan Waralaba (Franchising di Indonesia) Aspek Hukum dan Non Hukum. P.T. Citra Aditya Bakti. Bandung

Widjaya Gunawan. 2001. Waralaba. P.T. Grafindo Persada. Jakarta Widjaya. Gunawan. 2002. Seri 